\title{
Corruption, Democracy and Privately Financed Infrastructure
}

\begin{abstract}
Do political institutions moderate the influence of corruption on privately financed infrastructure projects? We argue that electoral competition increases the cost of corruption for private partners and focuses politicians' attention on providing projects with public (rather than private) benefits. Without such incentives, corruption is not contained and the private benefits of bribes and favorable contract terms are responsible for increasing numbers of projects. Studying 116 countries between 1984-2012, we find that as public sector corruption increases in democracies, no change in the number of projects is observed, while more projects emerge in non-democracies as corruption worsens.
\end{abstract}

(NB: Our response memorandum is included as an appendix for the convenience of any referee who has not commented on our initial submission.) 
Partnership agreements between government and the private sector are now used in more than 134 countries and contribute $15-20 \%$ of total infrastructure investment (World Bank 2014). They have enjoyed sustained support from international organizations. While widely adopted in developing countries, concerns about the fit of these privately financed projects with a global agenda on sustainable development are emerging (United Nations Department for Economic and Social Affairs 2016). There is consensus on the claims that private financing is no panacea, that "one size fits all" approaches are not adequate, and that political and regulatory risks-particularly corruption-should be assessed and mitigated. According to the World Economic Forum (2015), corruption represents a regulatory risk that applies throughout the life cycle of a project. The common denominator in these reports and policy briefs is an awareness that partnerships do not occur in a vacuum; they call for empirical studies that do not ignore the institutional settings in which projects are embedded. How do political institutions shape the influence of corruption on the adoption of privately financed infrastructure projects? We introduce and provide empirical support for a theory that electoral competition increases the cost of corruption for private partners and incentivizes politicians to focus on providing projects with public benefits, thus shaping the number of these projects at the national-level.

Investment in infrastructure has been shown to have a positive effect on aggregate economic performance (Aschauer 1989a, 1989b; Gramlich 1994; Röller and Waverman, 2001) and trade (Francois and Manchin, 2013). Consequently, developing countries have been encouraged to invest heavily in public infrastructure and to foster private involvement in such investment. For example, the World Bank describes investment in urban transport infrastructure as "one of the best ways to promote rural development" and private involvement in such investments as a way "to improve management skills, increase operating efficiency, and impose market discipline" (World Bank 2008, 3). However, recent 
studies have shown that investment in infrastructure is not unequivocally positive, and can generate negative spillovers (Puga 2002; Ottaviano 2008).

The interplay between weak political institutions and corruption can work against any development-boosting benefits of investment in public infrastructure (Flyvbjerg 2009; Pickrell 1992). For example, if a transitioning economy has a reputation for public sector corruption, private interest in public contracts may be driven by the prospect of exchanging bribes for favorable contract terms (Auriol and Picard 2013), rather than a desire to collaborate on a legitimate and productive project. Indeed, a "wagon wheel effect" (Berkovich, 2015) can ensue whereby in corrupt contexts pouring more funds into a given policy area can lead to less effective outcomes. Well-functioning democratic political institutions have been broadly shown to strengthen economic performance and to stimulate development (Acemoglu and Robinson 2012; Knack and Keefer 1995). We explore how the extent to which infrastructure projects are performed via partnerships is affected by the interaction of an essential element of democratic politics, electoral accountability, with public sector corruption. Public-private partnerships such as those we study have often been linked axiomatically with diminished democratic accountability, though they incorporate mechanisms that can enhance it in practice (Willems 2014), including significant input transparency (Reynaers and Grimmelikhuijsen 2015). Recent work links the characteristics of political institutions to the adoption of particular contractual forms of infrastructure partnerships (Bertelli 2019), but not directly to domestic electoral competition.

We offer a theory that electoral competition crowds out the influence of bureaucratic corruption in attracting private partners for infrastructure development. Two claims are tested. First, in contexts where electoral accountability is high, more public sector corruption does not change the number of projects. Democracy essentially "switches off" corruption as a mechanism for incentivizing private participation. Second, in contexts where electoral accountability is low, public sector corruption 
increases the number of partnership agreements made. Without the electoral pressures of competitive elections, corrupt politicians and public officials can create favorable conditions for private involvement through bribes and special arrangements.

To test our hypotheses, we study a large panel data set of public infrastructure projects with private participation in 116 low- and middle-income countries from 1984 to 2012. In these nations, meeting resource needs compels governments to find alternative routes to financing and operating facilities often involving private partners (Hammami, Ruhashyankiko and Yehoue 2006). Without private investment, governments may fail to deliver infrastructure to citizens (Hammami, et al 2006, 4). The large variation in the presence and strength of democracy in our sample allows us to investigate how electoral accountability shapes the influence of public sector corruption. We find empirical support for both hypotheses. By concentrating efforts on improving electoral accountability in the political sphere, the effects of public sector corruption might be counteracted.

\section{Corruption and infrastructure}

The variety of ways in which corruption can be classified (Graycar 2015; Graycar and Prenzler 2013) has prompted some scholars to adopt a pragmatic approach, clarifying how and why corruption is conceptualized in a specific manner in each study rather than privileging any specific classification or framework (Bussell 2015). Given our focus on the interplay between the behavior of the public administration and the unfurling of the democratic process, we conceptualize corruption in terms of the extent to which agents (public officials) can exploit their position to the detriment of their principals (voters and politicians). Our working definition of corruption is the abuse of entrusted power for private gain, which relies on "the illicit use of willingness to pay as a decision-making criteria" (RoseAckerman 2007, xvii). 
We examine a setting that is infamous for its potential for corruption: infrastructure. Golden and Picci $(2006,457)$ note that "[p]ublic works construction projects are especially vulnerable to collusion between elected officials, bureaucrats, and private contractors." Public works contracts and the construction sector rank highest on Transparency International's Bribe Payers' Index for petty, grand and private corruption (Hardoon and Heinrich 2011, 18). Beyond poor procurement, contract and investment decisions, Transparency International points out that construction-sector corruption is "detrimental to long-term growth prospects of countries, particularly in the developing world where sound and sustainable infrastructure is so important" (Hardoon and Heinrich 2011, 20).

A short strand of literature has specifically investigated the factors that influence the private involvement in public-private partnerships (PPPs). The findings have been mixed, with evidence of more corruption being associated with fewer PPPs (Hammami et al. 2006) as well as the opposite (Yang, Hou and Wang 2013). Iossa and Martimort (2014) theorize that a public official choosing a degree of contractual incompleteness may be both better informed regarding contracting costs and also biased in favor of the contractor. ${ }^{1}$ Favoring costly incomplete contracts that require future renegotiations gives private parties the chance to extract excess funds from the government. This argument complements a body of work showing that corruption explains the widespread use of post-contractual renegotiations in Latin American concessions (Guasch and Straub 2009). It also links to another strand of literature that investigates the extent to which PPPs help or hinder aspects of democratic health, such as transparency. Generally, PPPs have been criticized for their lack of transparency and existing evidence broadly supports this view (Grimsey and Lewis 2002; Estache 2003; Hood et al. 2006; Papadopoulos 2007), as well as underlining the complexity of initiating PPPs and the institutional flexibility that they require

\footnotetext{
${ }^{1}$ Indeed, different contractual arrangements have been shown to have tangible effects on the way in which PPPs are used, as demonstrated in the case of Portugal by Cunha Marquez and Berg (2011).
} 
(Jooste and Scott 2011). However, there are several informative qualitative studies that add nuance to this vision by recording instances where PPPs may enhance certain indicators of democratic vigor, such as input transparency (Reynaers and Grimmelikhuijsen 2015) or multiple accountability processes (Willems 2014).

\section{Theory}

Our argument about how public infrastructure provision is affected by corruption draws insights from literatures in political institutions, political economy and public administration. We begin by clarifying a set of key players and their motivations. Politicians want to be re-elected and, thus, do not want to be exposed as being involved in corruption. These politicians stand to gain electoral and monetary benefits from public infrastructure projects. Self-enrichment through kick-backs from profitmaximizing firms is one direct benefit. "Honest" electoral benefits accrue from being able to claim credit with voters for an infrastructure project, while "dishonest" benefits can be due to support from firms "bought" via a favorable contract. Bureaucratic administrators are not subject to the same electoral pressures as politicians, but are disinclined to risk losing their jobs or to suffer criminal penalties. They also, however, stand to gain monetary benefits from public infrastructure projects in the form of kickbacks, for example, and professional benefits in situations where both politicians and firms are amenable to corruption and the administrator can act as a facilitator, thus ingratiating herself with her political colleagues. $^{2}$

${ }^{2}$ This is in line with qualitative research that has unveiled the multi-level, multifarious and tightly interlaced nature of corruption relationships between the public and private sectors (for example, see Jancsics and Jávor 2013). 
We conceive of democracy in a minimal sense: when it is functioning, voters can hold their politicians to account through competitive elections (Schumpeter 1942; Przeworski et al. 2000). Public goods, infrastructure projects in our case, are necessary for the public's well-being, particularly in transitional economies where the infrastructure needed for growth may not yet exist (Aschauer 1989a, 1989b; Gramlich 1994; Röller and Waverman 2001). If democracy works well because of competitive electoral pressures, only those public goods that are most beneficial to citizens should be provided as a form of responsive policy making (Lake and Baum 2001). In this way, a well-functioning democracy with competitive elections inhibits the influence of corrupt practices. Politicians and bureaucratic administrators alike know that being discovered as corrupt is likely and comes with a high electoral or personal cost, i.e. elections or criminal penalties (Mohtadi and Roe 2003; Schumacher 2013; Stephenson 2015). When elections are competitive, various political players (political parties, interest groups and the media) have incentives to ensure that projects that serve the public are delivered. Armed with this information, voters can punish politicians accordingly, and knowing this, politicians are less willing to accept corrupt bureaucratic practices.

The more effective a democracy is in holding its representatives to account, the less misuse of public office for private gain we expect to see. We argue that this is manifest in the substitution of one stimulus for project partnerships, corrupt exchanges, by another, the commitment value of stable democratic political institutions. A well-functioning democracy attracts infrastructure development partners. This is because strong political institutions increase the credibility of commitments in transactions with the public sector (Henisz 2002). The nub of our argument is that while both corruption and democracy are incentive mechanisms for attracting firms to build more infrastructure projects, electoral competition crowds out the influence of bureaucratic corruption. Electoral competition focuses the attention of incumbent politicians on public benefits because they can convince voters to re-elect 
them by providing infrastructure. Corruption instead focuses attention on private benefits to bureaucrats (bribes) and private firms (favorable contract conditions). Our claim is that when elections are competitive, the importance of public benefits leads incumbent politicians to behave in ways that resist corruption (Bohara, Mitchell and Mittendorff 2004)_increasing public, while decreasing private benefits.

It is generally accepted that increased competition reduces corruption by diminishing the possibility of extracting economic rents, or excess profits (Rose-Ackerman 1996). However, the relationship between corruption and competition in procurement practices has been shown to be complex (Bliss and Di Tella 1997; Laffont and N'Guessan 1999; Ades and Di Tella 1999; Burguet and Che 2004; Compte et al. 2005). Indeed, Celentani and Ganuza's (2002, 1274) model shows that "contrary to conventional wisdom, the total effect [of competition on corruption] is everything but clear cut: more competition may lead to both higher or lower corruption". Their model is especially fitting for the kind of projects we examine because PPPs represent "a case in which the good to be procured is not homogeneous but can be produced at different quality levels and in which the agent has superior information about delivered quality [and] in exchange for a bribe...can assign the project to a firm he favors and hide the fact that it delivers lower quality than promised" (Celentani and Ganuza 2002, 1274). This is important for our theory because we expect that competitive elections will moderate downward an increased rate of PPPs associated with a corrupt public sector by ensuring that politicians pursue public rather than private benefits because of the likelihood of electoral sanction. Politicians have at least some degree of control over administrative corruption, and stand to gain from it. We argue that democracies in which administrative corruption is high are those in which electoral distortions suppress the benefits of competitive elections for accountability. 
Competitive elections, then, increase incentives for governments to provide infrastructure services to citizens. Furthermore, PPPs leave a great deal of discretion to both the administrator and the private partner, making them a particularly low-cost vehicle for rent-seeking. However, in democracies, corrupt transactions come at a higher cost for private partners. Corrupt autocratic politicians are simply more likely to have access to or control over the prosecutorial and fiduciary machinery of the state than leaders of democracies. As a result, corrupt democracies expose private partners to risk from rentseeking because they cannot credibly commit to the success of corrupt dealings in the way that autocrats can. We argue that in this way, electoral competitiveness counteracts the rent-seeking incentives of private partners in corrupt environments, and test the following claims.

Hypothesis 1: When elections are competitive, the number of partnership projects does not increase with corruption.

Hypothesis 2: When elections are not competitive, increasing corruption increases the number of partnership projects.

These hypotheses are particularly relevant in developing countries, given their need for infrastructure investment, uncertain tax base, and potential for unaccountable governments. Indeed, after a phase in which privatization and blurring boundaries between the public and private sectors had been seen as an effective way to decrease corruption, scholars have questioned whether the benefits of private participation were overstated (Hopkin and Rodríguez-Pose 2007). The spread of market principles and privatization seem to have worsened corruption in some sectors and countries (Holmes 2006). With corruption in the bidding process adversely impacting the cost and quality of infrastructure through the inefficient selection of firms and projects (Rose-Ackerman and Palifka 2016; Della Porta and Vannucci 2012). Such conditions can foment public discontent (Bonnet et al. 2012; Martimort and Straub 2009). 


\section{Data and Methods}

We study panel data on partnership agreements in transitional economies drawn from the World Bank's Private Participation in Infrastructure (PPI) Projects Database. The unit of analysis for this study is the country-year. Our dataset records projects and political-economic variables in 116 transitional economies, which are listed in Table A2 of the appendix. The agreements recorded were brought to "financial closure" between 1984-2012, meaning that private partners entered a contract for the investment of funds or the provision of services in the year that agreement was recorded (World Bank 2017). Private participation in the projects in our sample involves direct investment by private firms in infrastructure development.

Our dependent variable is the number of Privately Financed Infrastructure Projects. This count variable was created by identifying within each country-year how many new individual public infrastructure projects with private involvement involved at least one agreement that reached financial closure. An infrastructure project can be considered a bundle of agreements between public and private partners. We count only projects and not agreements when constructing our dependent variable. In Albania in 2002, for example, two distinct public infrastructure projects with private involvement were initiated with an average of three agreements per project. One project was energy related, specifically for electricity generation (Essegei Hydro Power Plants), whereas the other was utility related, specifically water and sewage management (Elbasan Water Supply and Wastewater Treatment Concession). Both were Rehabilitate-Operate-Transfer concession agreements for existing infrastructure. For the entry for Albania in 2002, then, our dependent variable takes a value of two.

We believe that the number of Privately Financed Infrastructure Projects is a particularly appropriate measure because it captures the margin of projects that can be attributed to the focus on private benefits in our theory. That is, the count of privately financed projects that occur in a given year 
in a given country records the nexus between politicians, public administrators and private partners at our argument's core. It is superior to a variety of alternative measures and has broad country coverage in the World Bank data we employ. For instance, it more directly captures project involvement than expenditure on public investment as a fraction of gross domestic product. Such investment shares are confounded by government ideology and strategy, as well as the ability to deliver infrastructure through full public management. Measuring the absolute monetary value of projects masks incentives for political actors and private partners alike to split single projects into various parts to increase opportunities for self-enrichment. We expect such behavior to be limited in practice; it is precisely the large scale, infrequency and complexity of these projects that generates opportunities for corruption. ${ }^{3}$

A disadvantage of our count measure is that it does not take into account the size or value of the projects, which might be important in terms of the scope for self-enrichment for the partners involved, but is inconsistently reported in our data source. ${ }^{4}$ However, the projects in our dataset are significant in terms of size because smaller projects excluded from the data "are usually not reported in major news sources, databases, government sites or other sources used by the database" (World Bank 2017). While we cannot distinguish whether the change in the number of projects owes to the number of firms

${ }^{3}$ Electoral regimes could create incentives to split projects, but the direction of influence is ambiguous: majoritarian regimes enhance accountability, while proportional regimes bring a wider variety of voices into the policy debate (Norris 1997). In unreported results, including an indicator for "first-past-thepost" systems in the full models in Table 2 reduces the sample size dramatically, but does not achieve statistical significance. Electoral formulas are largely time invariant and our fixed effects specifications are meant to address these and other unobserved time-invariant influences in the full sample.

${ }^{4}$ Total project investment is reported for approximately 40 percent of the sample in the preferred specifications. 
interested in government contracts or government advocacy for PPPs, we incorporate country-level fixed effects to eliminate the influence of such unobservables.

We examine an alternative dependent variable that captures the number of Privately Financed Greenfield Projects. Greenfield projects involve new construction on previously undeveloped land through Build-Operate-Transfer, Build-Lease-Transfer and Build-Own-Operate agreements. Because these are geographically targeted and visible construction projects, they are among the most likely to be influenced by electoral accountability as we have hypothesized (Bertelli 2019). Consequently, examining all projects constitutes a more conservative test than greenfield projects alone.

The principal independent variables of interest are Public Sector Corruption drawn from the Varieties of Democracy project (Coppedge et al. 2015), Competitive Executive Election, a binary indicator drawn from the DPI (Beck et al. 2001) and the interaction between the two. These are explained in turn.

Our public sector corruption measure aggregates expert survey responses to questions regarding public sector bribery and embezzlement (McMann et al. 2016, 7). The question capturing public sector corruption asks "[t]o what extent do public sector employees grant favors in exchange for bribes, kickbacks, or other material inducements, and how often do they steal, embezzle, or misappropriate public funds or other state resources for personal or family use?" We measure competiveness for executive elections because building infrastructure with private involvement is an executive function. Thus, we are also interested in the Varieties of Democracy measure of executive corruption which is based on the following, similarly worded question: "[h]ow routinely do members of the executive, or their agents grant favors in exchange for bribes, kickbacks, or other material inducements, and how often do they steal, embezzle, or misappropriate public funds or other state resources for personal or family use?" Figure 1 shows that the public sector measure correlates highly with, but retains some 
distinctiveness from the executive measure. Consequently, we include the Executive Corruption Differential (the executive minus the public sector measure) as a control variable to clarify the impacts of bureaucratic corruption, which is central to our theoretical argument.

\section{FIGURE 1 ABOUT HERE}

Our electoral competition variable indicates whether in each country-year the elections being held are competitive as indicated by the DPI's executive index of electoral competitiveness (EIEC). The EIEC captures executives who are elected directly or by an electoral college. Executives chosen by other bodies receive the same score as the electing body: competitively elected presidents and prime ministers receive a score of six (executive receives more than $75 \%$ of the vote) or seven (executive receives less than $75 \%$ of the vote). Specifically, our variable takes a value of one when EIEC has a value of six or seven and zero otherwise: all competitively elected presidents and prime ministers have scores of six or seven.

Because our theory claims that the presence of competitive executive elections moderates the impact of corruption, we call these "elections models." As an alternative to electoral competition measured in this way, we examine the impact of autocracy versus democracy. Democracy, as measured by the Polity IV project (Marshall, Gurr and Jaggers 2013), is captured in an ordinal scale where one indicates a score of six or greater (democracy), -1 a score of -6 or lower (autocracy), and zero for all other governments: higher values indicate more democratic governments. These thresholds for democracy and autocracy are widely recognized in the comparative political institutions literature (Przeworski et al. 2000). We call these specifications "democracy models".

We employ the following control variables in our full specifications. Average Agreements Per Project records the average number of agreements in an infrastructure project with private involvement during a country year from the PPI database. This is a proxy for the facility that a country has for 
forming complex partnerships in the year in which the dependent variable is recorded. We expect a positive effect on the number of projects. We also control for the number of Checks and Balances in the system using the DPI measure. More checks imply greater policy stability and such commitments are essential when forming complex partnerships. We anticipate that more checks will increase credible commitments and thus the number of projects.

Because our hypotheses require an interaction between corruption and democracy, our preferred models of the number of projects in country $i$ in year $t$ take the following general form:

$$
\begin{gathered}
\text { Projects }_{i t}=\alpha+\beta_{1} \text { Corruption }_{i t}+\beta_{2} \text { Democracy }_{i t}+\beta_{3}\left(\text { Corruption }_{i t} \times \text { Democracy }_{i t}\right)+\text { controls }+ \text { country } \\
\text { fixed effects }+ \text { error }
\end{gathered}
$$

Our dependent variable is an over-dispersed count and we employ a fixed-effects (FE) negative binomial estimator introduced by Hausman, Hall and Grilliches (1984). While scholars have argued that this is not a true fixed-effects approach (Allison and Waterman 2002); the country-specific effect is in fact removed through a scaling parameter (Greene 2008, 918). ${ }^{5}$ We adopt the FE estimator to examine the effects of corruption and democratic competition holding constant all unobserved, time-invariant

\footnotetext{
${ }^{5}$ For this reason, we estimate both the elections and democracy models using a fixed-effects Poisson regression - which does provide a fixed-effect by shifting the conditional mean function (Greene 2008, 916-17) — and report robust results in terms of signs, significance and relative magnitude as models S3 and S4 in Table A1 of the Appendix.
} 
characteristics at the country level. ${ }^{6}$ Summary statistics for variables in the elections and democracy models are presented in Table 1.

To ensure the robustness of our results, we estimate a variety of specifications. We estimate population-averaged or between-effects (BE) models to understand the between-country effect of corruption and democratic pressures. The elections models measure democracy in the foregoing equation using the competitive executive elections variable and are estimated with only theorized variables (Model 1 with FE, Model 3 with $\mathrm{BE}$ ) and full specifications include all control variables (Model 5 with FE, Model 7 with BE). The democracy models employ the democracy-to-autocracy indicator described above; theory-only (Model 2 with FE, Model 4 with BE) and full (Model 6 with FE, Model 8 with BE) specifications are likewise estimated. Each of the foregoing specifications are also estimated on samples of merchant agreements and greenfield projects. All models are estimated with robust standard errors.

\section{Results}

The results of all specifications are presented in Table 2. Model 5 is our preferred elections model on the basis of a substantially lower Bayesian information criterion (BIC), while the theory-only specification (Model 1) shows that our hypothesized effects are robust. Similarly, while Model 6 is the preferred democracy model, as it has a significantly smaller BIC than the theory-only specification in Model 2, the key variables show similar effect sizes and significance.

\footnotetext{
${ }^{6}$ Our cross-national focus allows for the identification of institutional determinants of different frequencies of partnership agreements, but what public sector corruption or competitive elections imply in different national contexts can vary significantly. However, our fixed-effects models consider any unobserved, country-level features. Moreover, because data that have been collected according to strict comparability criteria (World Bank 2017; Coppedge et al. 2015) such concerns are reduced.
} 


\section{TABLES 1 AND 2 ABOUT HERE}

The moderating effect of democratic institutions on corruption is evident in Table 2 . In all of the FE models, corruption on its own has a positive and significant impact on the number of projects, while its effect is null in the BE specifications. The coefficient of the interaction term is negative and statistically significant in all of the election models and in all but one of the democracy models (Model 8, the full BE specification). For the greenfield project only models (see Table A3 in the appendix), the interaction terms are negative and significant in all but one of the election models (Model 7, the full BE specification) and in the BE democracy models (Models 4 and 8). These results provide threshold evidence that in contexts where governments are held to account by competitive elections, the effect of public sector corruption is dampened. Examining only between-country differences masks our hypothesized influences in some cases, while exploiting the temporal variation in our data brings the interaction of corruption and democracy into sharp relief.

We find empirical support for both hypotheses derived from our theory. As corruption in the public sector increases in countries with competitive elections there is no effect on the number of public infrastructure projects. However, in those countries with non-competitive elections as corruption in the public sector increases, so does the number of public infrastructure projects. Figures 2 and 3 illustrate how these models confirm our hypotheses through the predicted incidence rate, which is in our case the number of projects per year. In panel (a) of Figure 2, the predicted number of all projects at the lowest level of corruption in the presence of a non-competitive executive election is 0.24 , or about one project every four years, with a $95 \%$ confidence interval ranging from 0.14 to 0.33 . This predicted rate gradually increases as public sector corruption rises to a statistically distinct $0.49(0.35,0.63)$, or one project every other year. In competitive systems, the predicted number of projects per year is always just above 0.8 , and while this is statistically much greater than in the case of non-competitive elections, 
increases in corruption do not change the prediction. As anticipated, the results for greenfield projects alone are similar with slightly stronger political influence. Notably, at the highest levels of corruption in the sample, the number of projects with and without competitive elections are not statistically distinguishable.

In panel (a) of Figure 3, the effects for competitive electoral systems are similar with a constant prediction of about 0.8 projects per year across corruption levels. For autocracies, total projects rise more steeply with the level of public sector corruption. The predicted annual number of all projects for the lowest level of corruption is $0.17(0.07,0.27)$, but this more than doubles at the mean level of corruption in the sample to $0.38(0.30,0.46)$. At the highest level of corruption in the sample, autocracies and democracies become statistically indistinguishable. These results are robust in panel (b) when only greenfield projects are considered. At the lower threshold of 0.85 on the standardized corruption scale, the number of greenfield projects becomes statistically indistinct between democracies and autocracies.

\section{FIGURES 2 AND 3 ABOUT HERE}

While all other models in Table 2 leverage within-country variance, models 3-4 and 7-8 are population-averaged estimators for the theory and full specifications respectively. For the full elections model (Model 7), in a randomly selected country with corruption one standard deviation below the mean, the marginal effect of holding a competitive executive election adds 4.21 projects $(1.82,6.60)$, but this drops to $1.22(0.75,1.67)$ when corruption is one standard deviation above the mean and the difference is statistically significant at the 0.05 level. By contrast, the marginal effect of a noncompetitive election is not statistically distinct from zero at either level of corruption. In the full democracy model (8), the marginal effect of democracy in a randomly selected country one standard deviation below the corruption sample mean is a gain of 4.19 projects $(1.96,6.41)$, which falls to 1.58 
$(0.62,2.53)$ for a randomly drawn country with corruption one standard deviation above the average level and these results are not different at conventional levels of statistical significance. The betweencountry effect of autocracy one standard deviation below is statistically indistinguishable from zero, while it is 1.82 projects for a country equivalently above the corruption mean and the latter effect is distinct from zero at the 0.10 level. The implication of these results is quite interesting. When comparing countries with our between estimator, it appears that corruption diminishes the positive effect of competitive elections on infrastructure projects. However, as corruption increases within a country that holds competitive executive elections it has no effect on project adoptions. Results are overwhelmingly similar for models of greenfield projects as shown in Table A3.

Our control variables also produce interesting results; the coefficient of the Checks and Balances variables is positive and almost always statistically significant across our specifications. This suggests that constraints on political activity are inviting to private involvement in infrastructure development (Henisz 2002). Interestingly, the coefficient of the Average Agreements per Project, a measure of the complexity and scale of the project, also has a positive and statistically significant coefficient consistent with our expectation.

For further robustness assessment of our models of all projects, we also estimated specifications including additional political and economic control variables (sources appear in parentheses below). Because these variables substantially reduce our sample size and provide substantively similar results, we present them in the appendix. Models S1 and S2 in Table A2 account for growth in gross domestic product (World Development Indicators) as well as the size of the construction sector (United Nations National Accounts) in the year before financial closure (to avoid endogeneity concerns that the new projects are adding to these measures). Both measures increase the number of projects. Our additional models also control for whether the executive can serve an additional term (DPI), which increases the 
number of projects, and the number of years that the executive has served in office (DPI), which decreases the number of projects. In all of these specifications, the negative coefficients on the interaction variables central to our theoretical claims are robust in statistical significance.

One might be concerned that unobserved changes within countries can influence elections, bureaucratic corruption, and the adoption of public-private partnerships. We argue that those features that influence changes in elections and corruption are unlikely to be the same as those that shape the adoption of PPPs. First, bureaucratic corruption is notoriously persistent, meaning that it is unlikely to respond to anything short of a direct, targeted campaign against bureaucratic corruption, and even these are ineffective (Meagher 2005; Svensson 2005; Persson et al. 2012). Second, while broader economic changes can influence electoral outcomes, it is unclear how they would influence bureaucratic corruption and we observe no such correlation. ${ }^{7}$ Moreover, the factors that determine whether or not elections are competitive vary significantly from country to country (e.g., Gottlieb and Kosec 2019). Third, although the private sector likely responds to economic improvement by seeking more involvement in infrastructure development, such changes are unlikely to have a strong effect on bureaucratic corruption and electoral competitiveness. ${ }^{8}$ And while good economic performance may increase the chance that an honest private partner seeks a project, we argue it is unlikely to disincentivize the partners - like those at the heart of our theory—who wish to self-enrich.

\footnotetext{
${ }^{7}$ In unreported results, bivariate within-country correlations between our corruption measure and the growth rate in GDP per capita and unemployment as a percentage of the labor force are not statistically significant.

${ }^{8}$ The polyserial correlation between our binary indicator of competitive elections and the growth rate of GDP per capita is just 0.066 and with unemployment as a percentage of the labor force is 0.156 .
} 


\section{Conclusion}

In this study we have analyzed the interplay between corruption and democratic institutions in shaping the incidence of privately financed infrastructure partnerships. We provide evidence that as corruption in the public sector increases in countries with competitive elections, there is no change in the predicted number of infrastructure projects. This suggests that functioning democratic institutions increase the cost of corruption for public and private partners alike and focus government efforts on providing goods for the public benefit. In contrast, countries with non-competitive elections are associated with an increase in the number of public infrastructure projects as corruption in the public sector increases. In such contexts, the cost of corruption for involved actors is contained, meaning that private partners are more willing to engage in malfeasant activities with corrupt representatives of the state.

Our analysis addresses calls to investigate the contextual dependencies of the influence of corruption (Svensson 2005). Consistent with our findings, studies have pointed to the fact that very short or very long political time horizons - as in the case of highly competitive democracies and autocracies, respectively - tend to produce higher levels of corruption. On the one hand, short time horizons create incentives for administrators to extort or solicit bribes in exchange for immediate favors (Campante, Chor and Do 2009; Fredrikson and Svensson 2003). Yet the threat of frequent replacement through elections also prevents those administrators from entering long-term corrupt deals with firms, which is often at the core of corruption in large infrastructure projects (Golden and Picci 2006; Hardoon and Heinrich 2011). On the other hand, potential private partners may be skeptical that incumbent administrators will be around long enough to respect their commitments (Milanovic, Hoff and Horowitz 2010). They may instead consider long-term governments (even autocrats) as ideal partners for a prolonged, possibly corrupt exchange. This is likewise consistent with qualitative evidence (de Graaf 
and Huberts 2008), which points to relationships between bribers and officials in which both parties trust one another. Such harmful trust is strengthened through corrupt networks (Jancsics and Jàvor 2012) and when corruption is not stigmatized, as is typically the case in contexts characterized by endemic corruption, new corrupt players can be easily incorporated (de Graaf and Huberts 2008, 647). While our aggregate level findings broadly support these micro-level studies, infrastructure partnerships are an important setting in which to examine the role of political institutions because they leave significant discretion with private partners and administrators. In so doing, we grant further empirical ammunitions to the view that in "corrupt project contexts $[\ldots]$ public administrators can use their arbitrary power especially where there are insufficient controls on how government officials behave" (Locatelli et al. 2017, 255-256). Future scholarship should seek to clarify the mechanisms by which micro-level corruption is enhanced and mitigated by particular configurations of political institutions.

Our findings refine and extend evidence from a small but important literature on the interplay between political institutions and PPPs. Yang et al. (2013) argue that the transitional nature of political institutions in their sample of countries may explain why they did not find the strong positive relationships between government capacity and credibility and PPP adoption they anticipated. They speculate that the absence of mature institutions leads to corruption, which, in turn, provides room for private sector development and for rent seeking by interest groups in the short term. Our findings are instructive because in autocracies, corruption can attract partnerships, while in democracies, competitive electoral pressures subdue the independent influence of corruption. While our theory adds an important argument to this literature, more empirical work should be done to discover whether the democratic crowding-out effect we postulate is successful in attracting "good" projects that are efficient and responsive to voter demand, rather than "bad" projects that inefficiently enrich administrators and firms and do not respond to the wants of the electorate. 
We offer a timely contribution to current policy debates as it focuses explicitly on the specific institutional settings in which infrastructure projects are embedded. In particular, while scholars have found ambiguity in the direction of causation between democratic governance and growth, economic expansion cannot begin unless reasonably well-functioning institutions are in place (Rose-Ackerman 2007). Building institutional capacity—such as the rule of law—in weak states, therefore, may be a promising avenue for international organizations trying to curb corruption (Jetter and Parmeter 2018). Speedy democratization is a consistent argument for radical change: a "big bang" innovation (Rothstein 2011) that can alter attitudes about democracy and corruption in a given country at the same time. Without downplaying the importance of investments in incremental modifications such as tightening procurement criteria (World Economic Forum 2015), we argue that improving democracy would make such investments more profitable. Our findings lend support to the notion that corruption is a systemic problem that should be tackled holistically, rather than with separate individual interventions (GansMorse et al. 2017). In particular, understanding the interaction between democracy and corruption may help international organizations and NGOs to design and to calibrate their interventions. In the same vein, the participation of civil society has been recognized as one of the most promising routes for tackling corruption and our findings do not challenge this argument. However, they do emphasize the importance of participation through rather than beyond the ballot box. 


\section{Bibliography}

Acemoglu, Daron, and James A. Robinson. 2012. Why Nations Fail: The Origins of Power, Prosperity, and Poverty. New York: Crown Business.

Ades, Alberto and Rafael Di Tella, 1997. National champions and corruption: Some unpleasant interventionist arithmetic. Economic Journal 107: 1023-1042.

Allison, Paul D., and Richard P. Waterman. 2002. Fixed-Effects Negative Binomial Regression Models. Sociological Methodology 32(1): 247-265.

Aschauer, David A.; 1989a. Is Public Expenditure Productive? Journal of Monetary Economics 23(2): 177-200.

Aschauer, David A., 1989b. Public Investment and Productivity Growth in the Group of Seven. Economic Perspectives 13(5): 17-25.

Auriol, Emmanuelle and Pierre M. Picard. 2013. A Theory of BOT Concession Contracts. Journal of Economic Behavior \& Organization 89: 187-209.

Beck, Thorsten, George Clarke, Alberto Gro, Philip Keefer, and Patrick Walsh. 2001. New Tools in Comparative Political Economy: The Database of Political Institutions. World Bank Economic Review 15(1): $165-176$.

Berkovich, Izhak. 2015. The Corrupted Industry and the "Wagon-Wheel Effect", Administration \& Society, 48(5): 559-579.

Bertelli, Anthony M. 2019. Public Goods, Private Partnerships, and Political Institutions. Journal of Public Administration Research and Theory, 29(1): 67-83.

Bliss, Christopher and Rafael Di Tella. 1997. Does competition kill corruption? Journal of Political Economy 105, 1001-1023.

Bohara, Alok K., Neil J. Mitchell, and Carl F. Mittendorff. 2004. Compound Democracy and the Control of Corruption: A Cross-Country Investigation. Policy Studies Journal 32(4): 481-499.

Bonnet, Celine, Pierre Dubois, David Martimort, and Stephane Straub. 2012. Empirical Evidence on Satisfaction with Privatization in Latin America. World Bank Economic Review 26(1): 1-33.

Burguet, Roberto and Che, Yeon-Koo. 2004. Competitive procurement with corruption. RAND Journal of Economics, 50-68.

Bussell, Jennifer. 2015. Typologies of Corruption: A Pragmatic Approach. In Greed, Corruption, and the Modern State: Essays in Political Economy edited by Susan Rose-Ackerman and Paul Lagunes. Cheltenham: Edward Elgar Publishing. 
Campante, Filipe R., Davin Chor, and Quoc-Anh Do. 2009. Instability and the Incentives for Corruption. Economics \& Politics 21(1): 42-92.

Celentani, Marco and Ganuza, Juan-José. 2002. Corruption and competition in procurement. European Economic Review, 46(7), 1273-1303.

Compte, Olivier, Lambert-Mogiliansky, Ariane and Verdier, Thierry. 2005. Corruption and competition in procurement auctions. Rand Journal of Economics, 1-15.

Coppedge, Michael, John Gerring, Staan I. Lindberg, Jan Teorell, David Altman, Michael Bernhard, Steven Fish, Adam Glynn, Allen Hicken, Carl Henrik Knutsen et al. 2015. Varieties of Democracy: Dataset v5. Varieties of Democracy $(V$-Dem) Project.

Cunha Marques Rui, Berg Sanford. 2011. Public-private Partnership Contracts: A Tale of Two Cities with Different Contractual Arrangements. Public Administration 89(4):1585-603.

De Graaf, Gjalt, and Leo W. Huberts. 2008. Portraying the Nature of Corruption using an Explorative Case Study Design. Public Administration Review 68(4): 640-653.

della Porta, Donatella, and Alberto Vannucci. 2012. When Anti-Corruption Policy Fails: The Italian Case Eighteen Years after the Mani Pulite Investigations. In The Social Construction of Corruption in Europe edited by Dirk Tanzler, Konstadinos Maras, and Angelos Giannakopoulos. Farnham: Ashgate Publishing.

Flyvbjerg, Bent. 2009. Survival of the Unfittest: Why the Worst Infrastructure Gets Built and What We Can Do About It. Oxford Review of Economic Policy 25(3): 344-367.

Francois, Joseph and Miriam Manchin. 2013. Institutions, Infrastructure, and Trade in World Development 46: 165-175.

Fredriksson, Per G., and Jakob Svensson. 2003. Political Instability, Corruption and Policy Formation: The Case of Environmental Policy. Journal of Public Economics 87(7): 1383-1405.

Gans-Morse, Jordan, Mariana Borges, Alexey Makarin, Theresa Mannah-Blankson, Andre Nickow, and Dong Zhang. 2018. Reducing Bureaucratic Corruption: Interdisciplinary Perspectives on What Works. World Development 105: 171-188.

Golden, Miriam, and Lucio Picci. 2006. Corruption and the Management of Public Works in Italy. In International Handbook on the Economics of Corruption edited by Susan Rose-Ackerman. Cheltenham: Edward Elgar Publishing.

Gottlieb, Jessica, and Katrina Kosec. 2019. The countervailing effects of competition on public goods provision: When bargaining inefficiencies lead to bad outcomes, American Political Science Review, 113(1): 88-107. 
Gramlich, Edward. 1994. Infrastructure Investment: A Review Essay. Journal of Economic Literature 32(3): 1176-1196.

Graycar, Adam. 2015. Corruption: Classification and Analysis. Policy and Society 34(2): 87-96.

Graycar, Adam, and Tim Prenzler. 2013. Understanding and Preventing Corruption. New York: Palgrave MacMillan.

Greene, William H.. 2008. Econometric Analysis. $6^{\text {th }}$ Edition. Upper Saddle River, NJ: Prentice Hall.

Grimsey, Darrin and Mervyn Lewis. 2002. Accounting for Public Private Partnerships. Accounting Forum, 26(3): 245-70.

Guasch, J. Luis, and Stephane Straub. 2009. Corruption and Concession Renegotiations: Evidence from the Water and Transport Sectors in Latin America. Utilities Policy 17(2): 185-190.

Hammami, Mona, Jean-François Ruhashyankiko, and Etienne B. Yehoue. 2006. Determinants of PublicPrivate Partnerships in Infrastructure. IMF Working Paper WP/06/99.

Hardoon, Deborah, and Finn Heinrich. 2011. Bribe Payers Index 2011. Transparency International: https://www.transparency.org/bpi2011/results

Hausman, Jerry, Bronwyn H. Hall, and Zvi Griliches. 1984. Econometric Models for Count Data with an Application to the Patents-R\&D Relationship. Econometrica 52(4): 909-938.

Henisz, Witold. 2002. The Institutional Environment for Infrastructure Investment. Industrial and Corporate Change 11(2): 355-389.

Holmes, Leslie. 2006. Rotten states?: Corruption, Post-Communism, and Neoliberalism. Duke University Press.

Hood, John, Ian Fraser and Neil McGarvey. 2006. Transparency of Risk and Reward in UK PublicPrivate Partnerships. Public Budgeting \& Finance 26(4): 40-58.

Hopkin, Jonathan, and Andrés Rodríguez-Pose. 2007. "Grabbing Hand" or "Helping Hand"?: Corruption and the Economic Role of the State. Governance 20(2): 187-208.

Iossa, Elisabetta, and David Martimort. 2014. Corruption in Public-Private Partnerships, Incentives and Contract Incompleteness. International Journal of Industrial Organization 44 (2016): 85-100.

Jancsics, David, and Istvàn Jávor. 2012. The Role of Power in Organizational Corruption: An Empirical Study, International Public Management Journal 48(5): 527-558.

Jetter, Michael. and Parmeter, Christopher. 2018. Sorting through Global Corruption Determinants: Institutions and Education Matter-Not Culture. World Development, 109: 279-294. 
Jooste, Stephan, and Scott, Richard. 2011. The Public-Private Partnership Enabling Field, Administration \& Society 44(2): 149-182.

Knack, Stephen, and Philip Keefer. 1995. Institutions and Economic Performance: Cross-Country Tests using Alternative Institutional Measures. Economics \& Politics 7(3): 207-227.

Laffont, Jean-Jacques and Tchétché N'Guessan. 2000. Group lending with adverse selection. European Economic Review 44.4-6: 773-784.

Lake, David A., and Matthew A. Baum. 2001. The Invisible Hand of Democracy: Political Control and the Provision of Public Services. Comparative Political Studies 34(6): 587-621.

Locatelli, Giorgio, Giacomo Mariani, Tristano Sainati, and Marco Greco. 2017. Corruption in public projects and megaprojects: There is an elephant in the room! International Journal of Project Management 35(3): 252-268.

Marshall, Monty G., Ted R. Gurr and Keith Jaggers. 2013. Polity IV Project: Political Regime Characteristics and Transitions, 1800-2014. Dataset User's Manual. College Park, MD: Center for Systemic Peace.

Martimort, David, and Stephane Straub. 2009. Infrastructure Privatization and Changes in Corruption Patterns: The Roots of Public Discontent. Journal of Development Economics 90(1): 69-84.

McMann, Kelly M., Daniel Pemstein, Brigitte Seim, Jan Teorell and Staan I. Lindberg. 2016. Strategies of Validation: Assessing the Varieties of Democracy Corruption Data. V-Dem Working Paper 23.

Meagher, Patrick. 2005. Anti-Corruption Agencies: Rhetoric Versus Reality. Journal of Policy Reform 8(1): 69-103.

Milanovic, Branko, Karla Hoff, and Shale Horowitz. 2010. Turnover in Power as a Restraint on Investing in Influence: Evidence from the Postcommunist Transition. Economics \& Politics 22(3): 329361.

Mohtadi, Hamid, and Terry L. Roe. 2003. Democracy, Rent Seeking, Public Spending and Growth. Journal of Public Economics 87(3): 445-466.

Norris, Pippa. 1997. Choosing Electoral Systems: Proportional, Majoritarian and Mixed Systems. International Political Science Review 18(3): 297-312

Ottaviano, Gianmarco. 2008. Infrastructure and Economic Geography: An Overview of Theory and Evidence. EIB papers 13(2): 8-35.

Papadopoulos, Yannis. 2007. Problems of Democratic Accountability in Network and Multilevel Governance. European Law Journal, 13(4): 469-86. 
Persson, Anna, Bo Rothstein and Jan Teorell. 2013. Why Anticorruption Reforms Fail—Systemic Corruption as a Collective Action Problem. Governance 26(3): 449-471.

Pickrell, Don H.. 1992. A Desire Named Streetcar: Fantasy and Fact in Rail Transit Planning. Journal of the American Planning Association 58(2): 158-176.

Przeworski, Adam, Michael E. Alvarez, Jose A. Cheibub, and Fernando Limongi. 2000. Democracy and Development. New York: Cambridge Univ. Press.

Puga, Diego. 2002. European Regional Policies in Light of Recent Location Theories. Journal of Economic Geography 2(4): 373-406.

Reynaers, Anne-Marie and Stephan Grimmelikhuijsen. 2015. Transparency in Public-Private Partnerships: Not So Bad After All? Public Administration 93(3): 609-626.

Röller, Lars-Hendrik, and Leonard Waverman. 2001. Telecommunications Infrastructure and Economic Development: A Simultaneous Approach. American Economic Review 91(4): 909-923.

Rose-Ackerman, Susan, 1996. Redesigning the state to fight corruption. Public Policy for Private Sector, World Bank.

Rose-Ackerman, Susan, 2007. International Handbook on the Economics of Corruption. Cheltenham: Edward Elgar Publishing.

Rose-Ackerman, Susan, and Bonnie J. Palifka. 2016. Corruption and Government: Causes, Consequences, and Reform. Cambridge: Cambridge University Press.

Rothstein, Bo. 2011. The quality of government: Corruption, social trust, and inequality in international perspective. University of Chicago Press.

Schumacher, Ingmar. 2013. Political Stability, Corruption and Trust in Politicians. Economic Modelling 31: 359-369.

Schumpeter, Joseph A. 1942. Capitalism, Socialism and Democracy. New York: Harper \& Row.

Stansbury, Neill. 2005. Exposing the Foundations of Corruption in Construction. In Global Corruption Report 2005: Corruption in construction and Post-Conflict Reconstruction, edited by Diana Rodriguez, Gerard Waite, and Toby Wolfe. Transparency International:

https://www.transparency.org/whatwedo/publication/global_corruption_report_2005_corruption_in_con struction_and_post_conflict

Stephenson, Matthew C. 2015. Corruption and Democratic Institutions: A Review and Synthesis. In Greed, Corruption, and the Modern State: Essays in Political Economy edited by Susan Rose-Ackerman and Paul Lagunes. Cheltenham: Edward Elgar Publishing.

Svensson, Jakob. 2005. Eight Questions about Corruption. Journal of Economic Perspectives 19(3): 1942. 
United Nations. 2017. UN Economic and Social Council Partnership Forum. Partnerships for Promoting Opportunities, Increased Prosperity and Sustainable Development for All:

https://www.un.org/ecosoc/sites/www.un.org.ecosoc/files/files/en/2017doc/20170607_ECOSOC\%20Par tnership\%20Forum\%20Summary.pdf

United Nations, Department of Economic and Social Affairs (UN DESA). 2016. "Public-Private Partnerships and the 2030 Agenda for Sustainable Development: Fit for purpose?":

http://www.un.org/esa/desa/papers/2016/wp148_2016.pdf

Wei, Shang-Jin. 2000. How Taxing Is Corruption on International Investors? Review of Economics and Statistics 82(1): 1-11.

Willems, Tom. 2014. Democratic Accountability in Public-Private Partnerships: The Curious Case of Flemish School Infrastructure. Public Administration, 92(2): 340-358.

World Bank. 2008. Safe, Clean, and Affordable: Transport for Development. World Bank Transport Business Strategy 2008-2012:

http://siteresources.worldbank.org/INTTRANSPORT/Resources/336291-

1211381200616/Transport_Business_Strategy_web.pdf

World Bank. 2014. World Bank Group Support to Public-Private Partnerships: Lessons from Experience in Client Countries, fy02-12:

http://ieg.worldbankgroup.org/sites/default/files/Data/reports/ppp_eval_updated2_0.pdf

World Bank. 2017. "Private Participation in Infrastructure Database" Methodology Section: http://ppi.worldbank.org/methodology/ppi-methodology

World Economic Forum Report. "Strategic Infrastructure Mitigation of Political \& Regulatory Risk in Infrastructure Projects". Retrieved (December 2017) at:

http://www3.weforum.org/docs/WEF_Risk_Mitigation_Report_2015.pdf

Yang, Yongheng, Yilin Hou, and Youqiang Wang. 2013. On the Development of Public-Private Partnerships in Transitional Economies: An Explanatory Framework. Public Administration Review 73(2): 301-310. 
Table 1: Summary Statistics

\begin{tabular}{|c|c|c|c|c|}
\hline \multicolumn{5}{|l|}{ Full Elections Model } \\
\hline Variable & Mean & Std. Dev. & Max. & Min. \\
\hline Total Projects & 1.814 & 7.838 & 153 & 0 \\
\hline Merchant Agreements & 0.197 & 0.847 & 23 & 0 \\
\hline Greenfield Projects & 1.051 & 4.534 & 70 & 0 \\
\hline Public Sector Corruption & 0.623 & 0.243 & 0.975 & 0.042 \\
\hline Comp. Exec. Election & 0.610 & 0.488 & 1 & 0 \\
\hline Exec. Corruption Differential & 0.011 & 0.136 & 0.590 & -0.506 \\
\hline Avg. Agreements Per Project & 1.376 & 3.373 & 24 & 0 \\
\hline Checks and Balances & 2.401 & 1.682 & 18 & 1 \\
\hline \multicolumn{5}{|l|}{ Full Democracy Model } \\
\hline Variable & Mean & Std. Dev. & Max. & Min. \\
\hline Number of Projects & 1.877 & 7.988 & 153 & 0 \\
\hline Merchant Agreements & 0.200 & 0.858 & 23 & 0 \\
\hline Greenfield Projects & 1.087 & 4.620 & 70 & 0 \\
\hline Public Sector Corruption & 0.625 & 0.245 & 0.975 & 0.042 \\
\hline Democracy & 0.097 & 0.817 & 1 & -1 \\
\hline Exec. Corruption Differential & 0.017 & 0.133 & 0.590 & -0.501 \\
\hline Avg. Agreements Per Project & 1.381 & 3.366 & 24 & 0 \\
\hline Checks and Balances & 2.444 & 1.690 & 18 & 1 \\
\hline
\end{tabular}


Table 2: Electoral Competition, Democracy and Public Sector Corruption Effects on the Number of Infrastructure Projects, Negative Binomial Regression Results, 1984-2012.

\begin{tabular}{|c|c|c|c|c|c|c|c|c|}
\hline & (1) & (2) & (3) & (4) & $(5) \dagger$ & $(6) \div$ & (7) & $(8)$ \\
\hline & $\begin{array}{l}\text { Elec. } \\
\text { Theory }\end{array}$ & $\begin{array}{l}\text { Dem. } \\
\text { Theory }\end{array}$ & $\begin{array}{l}\text { Elec. } \\
\text { Theory }\end{array}$ & $\begin{array}{l}\text { Dem. } \\
\text { Theory }\end{array}$ & Elec. Full & Dem. Full & Elec. Full & Dem. Full \\
\hline \multirow[t]{2}{*}{ Public Sector Corruption } & $1.003^{* * *}$ & $0.876^{* * *}$ & 0.613 & -1.022 & $0.930^{* *}$ & $0.760^{* * *}$ & 0.479 & -1.298 \\
\hline & $(0.372)$ & $(0.248)$ & $(0.860)$ & $(0.869)$ & $(0.372)$ & $(0.259)$ & $(0.919)$ & $(0.944)$ \\
\hline \multirow[t]{2}{*}{ Comp. Exec. Election $(=1)$} & $1.511^{* * *}$ & & $2.570^{* * *}$ & & $1.400^{* * *}$ & & $1.717^{*}$ & \\
\hline & $(0.275)$ & & $(0.949)$ & & $(0.276)$ & & $(0.986)$ & \\
\hline \multirow[t]{2}{*}{ CEE*Corruption } & $-0.883^{* *}$ & & $-3.341^{* * *}$ & & $-0.835^{* *}$ & & $-3.025^{* * *}$ & \\
\hline & $(0.392)$ & & $(0.724)$ & & $(0.389)$ & & $(0.703)$ & \\
\hline \multirow[t]{2}{*}{ Exec. Corr. Differential } & -0.344 & $-0.647^{* *}$ & 3.105 & 2.977 & -0.353 & -0.485 & 3.659 & 3.675 \\
\hline & $(0.315)$ & $(0.323)$ & $(2.260)$ & $(2.478)$ & $(0.318)$ & $(0.324)$ & $(2.431)$ & $(2.610)$ \\
\hline \multirow[t]{2}{*}{ Democracy } & & $0.797^{* * *}$ & & 0.896 & & $0.806^{* * *}$ & & 0.531 \\
\hline & & $(0.171)$ & & $(0.675)$ & & $(0.179)$ & & $(0.634)$ \\
\hline \multirow[t]{2}{*}{ Democracy*Corruption } & & $-0.422^{*}$ & & $-0.866^{*}$ & & $-0.644^{* *}$ & & -0.694 \\
\hline & & $(0.247)$ & & $(0.486)$ & & $(0.256)$ & & $(0.464)$ \\
\hline \multirow[t]{2}{*}{ Avg. Agmts. Per Project } & & & & & $0.106^{* * *}$ & $0.101^{* * *}$ & $0.174^{* * *}$ & $0.170^{* * *}$ \\
\hline & & & & & $(0.005)$ & $(0.005)$ & $(0.009)$ & $(0.008)$ \\
\hline \multirow[t]{2}{*}{ Checks and Balances } & & & & & 0.025 & $0.064^{* * *}$ & $0.230^{* * *}$ & $0.172^{* *}$ \\
\hline & & & & & $(0.020)$ & $(0.015)$ & $(0.061)$ & $(0.073)$ \\
\hline \multirow[t]{2}{*}{ Constant } & $-1.660^{* * *}$ & $-1.087^{* * *}$ & -0.323 & 0.965 & $-1.892^{* * *}$ & $-1.428^{* * *}$ & -0.786 & 0.395 \\
\hline & $(0.261)$ & $(0.171)$ & $(0.972)$ & $(0.731)$ & $(0.262)$ & $(0.183)$ & $(1.066)$ & $(0.887)$ \\
\hline Observations & 3,204 & 3,166 & 3,212 & 3,182 & 3,117 & 2,995 & 3,125 & 3,015 \\
\hline $\mathrm{BIC}$ & $6,491.52$ & $6,490.76$ & & & $5,973.33$ & $5,895.33$ & & \\
\hline Country Effects & Within & Within & Between & Between & Within & Within & Between & Between \\
\hline
\end{tabular}


Figure 1: Correlation Between Executive and Public Sector Corruption Measures. Shaded region represents $95 \%$ confidence interval from bivariate regression.

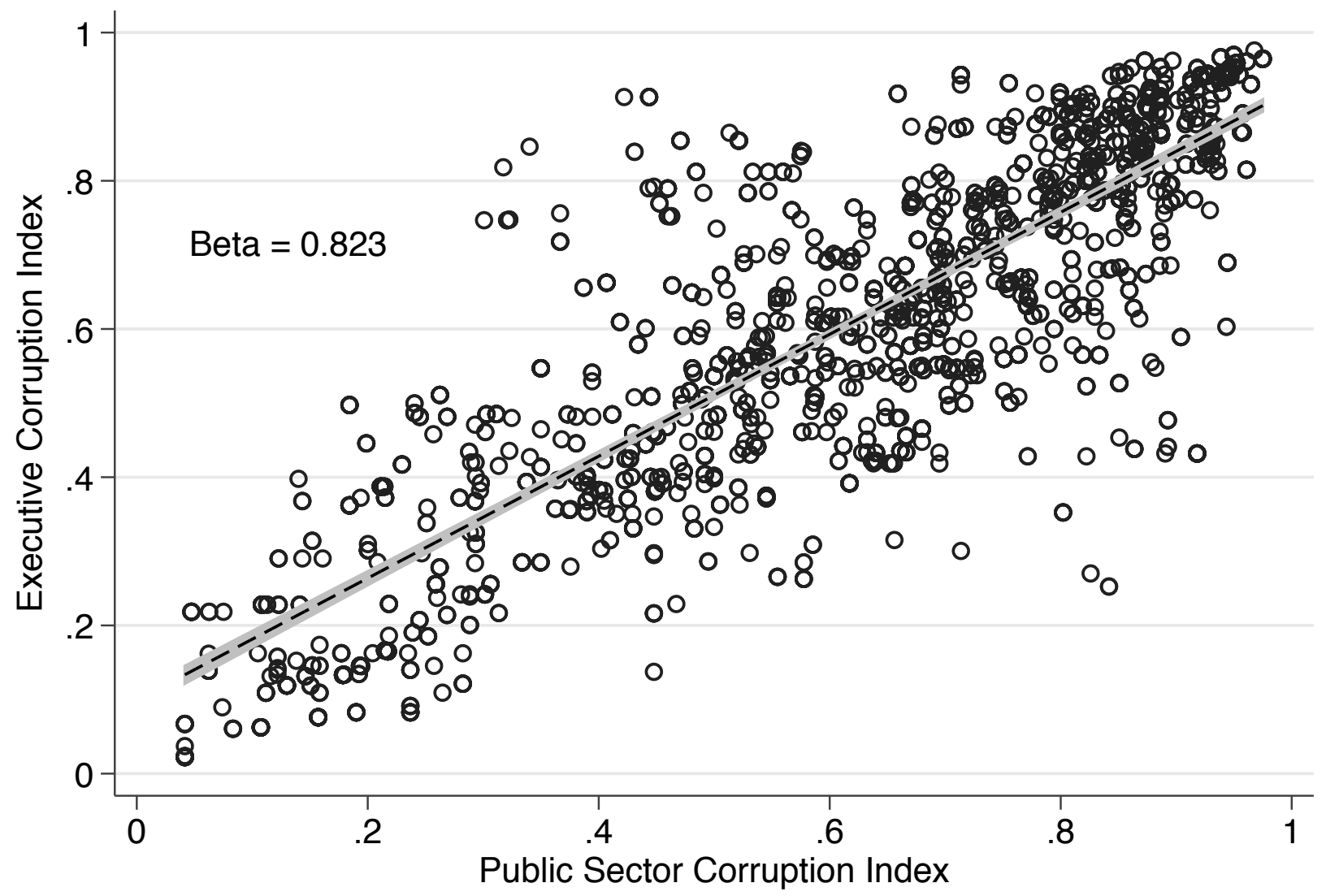


Figure 2: Project Incidence Ratios by Executive Electoral Competitiveness and Corruption Level. Predictions assume a country fixed effect of zero.

(a) Total Projects

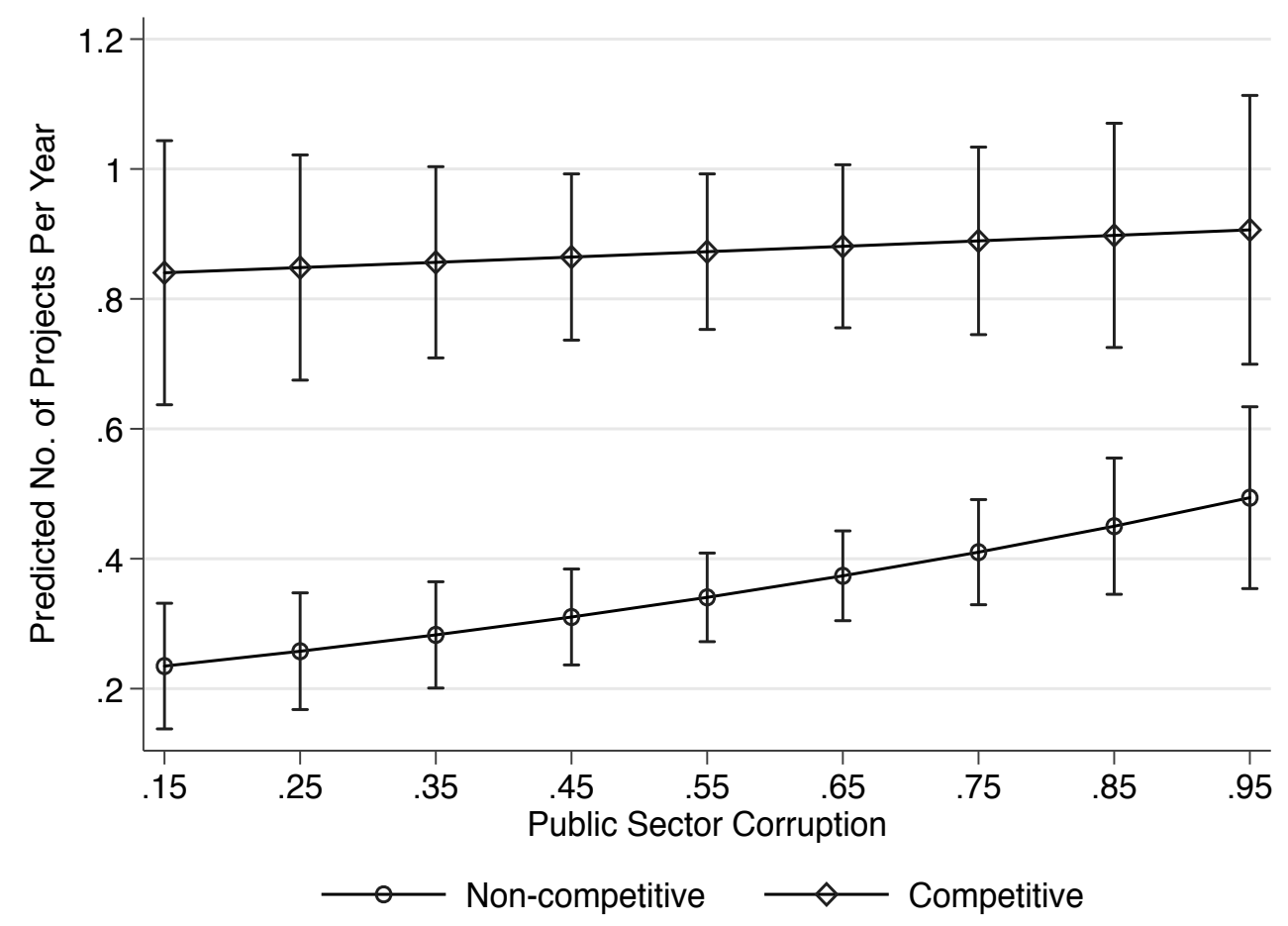

(b) Greenfield Projects

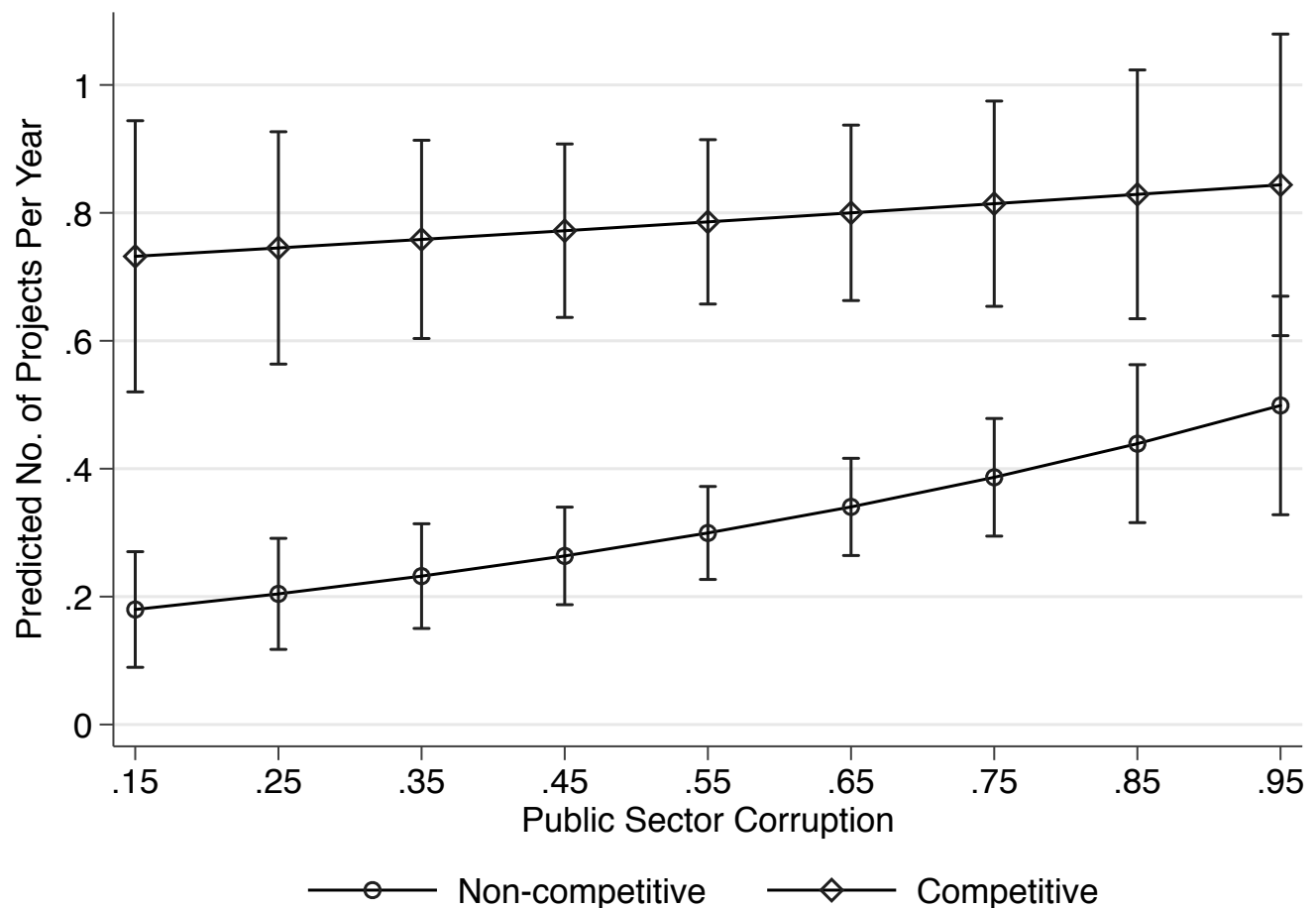


Figure 3: Project Incidence Ratios for Autocracy and Democracy by Corruption Level. Predictions assume a country fixed effect of zero.

(a) Total Projects

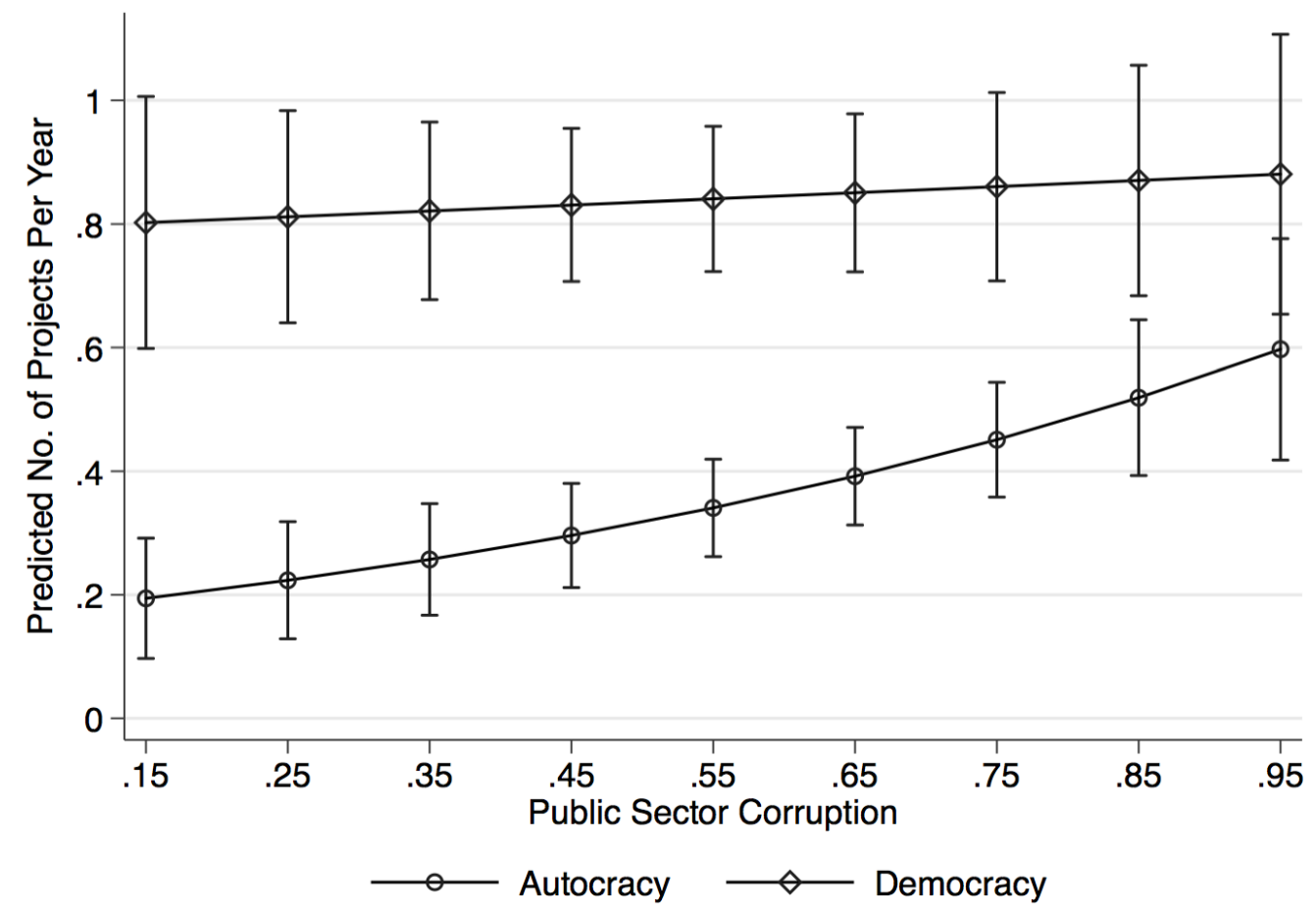

(b) Greenfield Projects

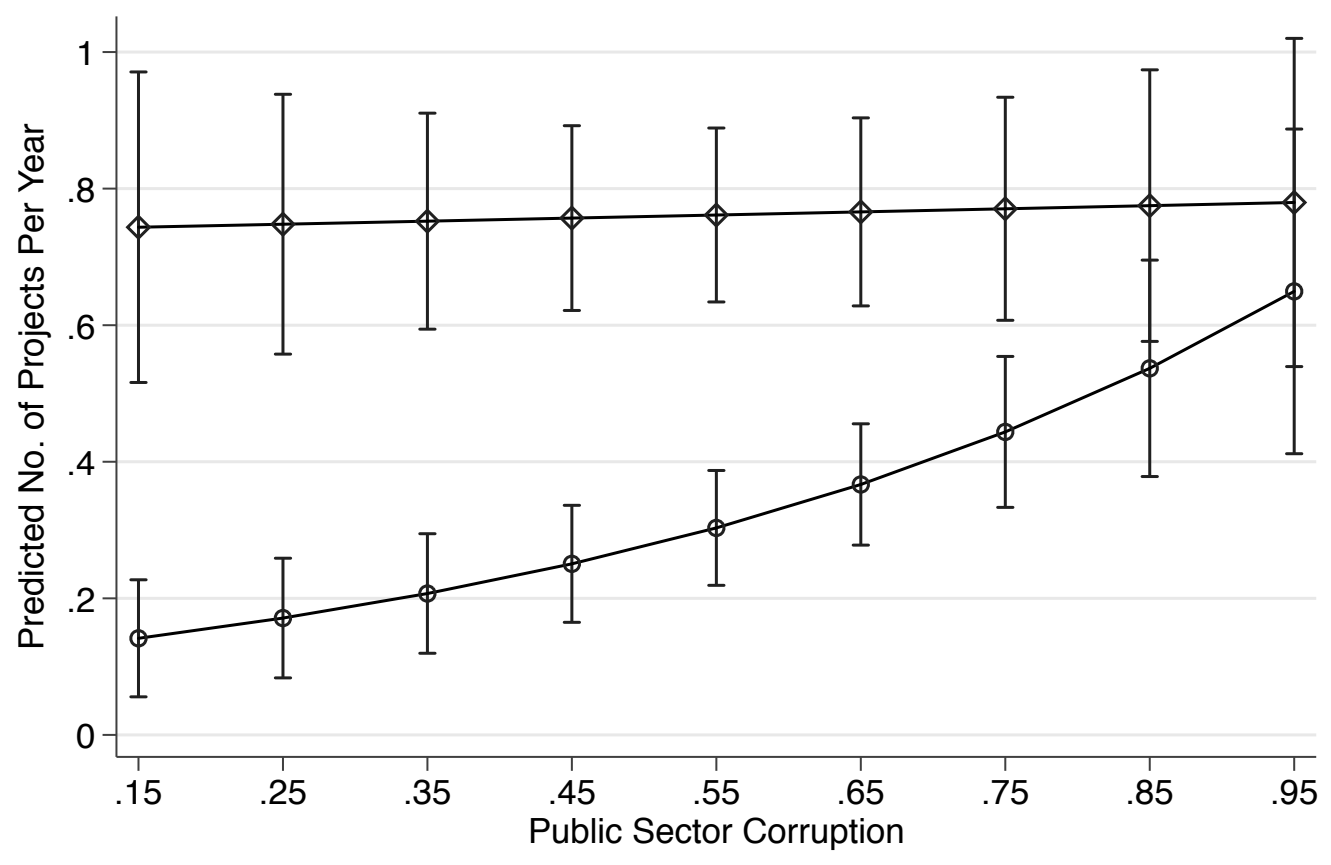

$\multimap$ Autocracy Democracy 


\section{Appendix (Not for Publication)}

Table A1: Electoral Competition, Democracy and Public Sector Corruption Effects on the Number of Infrastructure Projects, Fixed Effects Negative Binomial, Fixed Effects Poisson Regression Results, 1984-2012

\begin{tabular}{|c|c|c|c|c|}
\hline & $(\mathrm{S} 1)$ & $(\mathrm{S} 2)$ & (S3) & (S4) \\
\hline & $\begin{array}{c}\text { Elec. } \\
\text { Controls }\end{array}$ & $\begin{array}{c}\text { Dem. } \\
\text { Controls }\end{array}$ & $\begin{array}{c}\text { Elec. } \\
\text { Poisson }\end{array}$ & $\begin{array}{c}\text { Dem. } \\
\text { Poisson }\end{array}$ \\
\hline \multirow[t]{2}{*}{ Public Sector Corruption } & 0.742 & $0.591^{*}$ & $3.049^{* *}$ & 1.399 \\
\hline & $(0.504)$ & $(0.333)$ & $(1.500)$ & $(1.329)$ \\
\hline \multirow[t]{2}{*}{ Comp. Exec. Election $(=1)$} & $1.359^{* * *}$ & & $3.278^{* * *}$ & \\
\hline & $(0.350)$ & & $(1.003)$ & \\
\hline \multirow[t]{2}{*}{$\mathrm{CEE}^{*}$ Corruption } & $-0.894^{*}$ & & $-3.947^{* *}$ & \\
\hline & $(0.503)$ & & $(1.899)$ & \\
\hline \multirow[t]{2}{*}{ Exec. Corr. Differential } & -0.423 & -0.499 & -1.763 & $-2.157^{*}$ \\
\hline & $(0.353)$ & $(0.358)$ & $(1.191)$ & $(1.125)$ \\
\hline \multirow[t]{2}{*}{ Democracy } & & $0.778^{* * *}$ & & $2.105^{* * *}$ \\
\hline & & $(0.226)$ & & $(0.543)$ \\
\hline \multirow[t]{2}{*}{ Democracy*Corruption } & & $-0.679^{* *}$ & & $-2.416^{* * *}$ \\
\hline & & $(0.319)$ & & $(0.869)$ \\
\hline \multirow[t]{2}{*}{ Avg. Agmts. Per Project } & $0.098^{* * *}$ & $0.095^{* * *}$ & $0.066^{* * *}$ & $0.063^{* * *}$ \\
\hline & $(0.006)$ & $(0.006)$ & $(0.015)$ & $(0.015)$ \\
\hline \multirow[t]{2}{*}{ Checks and Balances } & 0.032 & $0.058^{* * *}$ & $0.031^{* * *}$ & $0.030^{* *}$ \\
\hline & $(0.019)$ & $(0.016)$ & $(0.011)$ & $(0.013)$ \\
\hline \multirow[t]{2}{*}{ Size of Construction Sector (Prev. Yr.) } & $0.066^{* * *}$ & $0.064^{* * *}$ & & \\
\hline & $(0.018)$ & $(0.017)$ & & \\
\hline \multirow[t]{2}{*}{ GDP Growth (Prev. Yr.) } & $0.004^{* *}$ & $0.004^{* *}$ & & \\
\hline & $(0.002)$ & $(0.002)$ & & \\
\hline \multirow[t]{2}{*}{ Term-limited Executive $(=1)$} & $-0.296^{* * *}$ & $-0.236^{* *}$ & & \\
\hline & $(0.113)$ & $(0.112)$ & & \\
\hline \multirow[t]{2}{*}{ Executive's No. of Years in Office } & $0.031^{* * *}$ & $0.031^{* * *}$ & & \\
\hline & $(0.007)$ & $(0.007)$ & & \\
\hline \multirow[t]{2}{*}{ Constant } & $-2.118^{* * *}$ & $-1.657^{* * *}$ & & \\
\hline & $(0.359)$ & $(0.255)$ & & \\
\hline Observations & 2,177 & 2,151 & 3,117 & 2,995 \\
\hline $\mathrm{BIC}$ & $5,011.11$ & $4,991.038$ & $9,971.38$ & $9,884.97$ \\
\hline
\end{tabular}

Standard errors in parentheses. Significance: ${ }^{*} p<0.10,{ }^{* *} p<0.05,{ }^{* * *} p<0.01$. 


\section{Table A2: Country Coverage}

\begin{tabular}{|l|l|l|}
\hline Afghanistan & Gabon & Niger \\
\hline Albania & Gambia, The & Nigeria \\
\hline Algeria & Georgia & Pakistan \\
\hline Angola & Ghana & Panama \\
\hline Argentina & Guatemala & Papua New Guinea \\
\hline Armenia & Guinea & Paraguay \\
\hline Azerbaijan & Guinea-Bissau & Peru \\
\hline Bangladesh & Guyana, CR & Philippines \\
\hline Belarus & Haiti & Romania \\
\hline Benin & Honduras & Russian Federation \\
\hline Bhutan & India & Rwanda \\
\hline Bolivia & Indonesia & Senegal \\
\hline Bosnia and Herzegovina & Iran & Sierra Leone \\
\hline Botswana & Iraq & Solomon Islands \\
\hline Brazil & Jamaica & Somalia \\
\hline Bulgaria & Jordan & South Africa \\
\hline Burkina Faso & Kazakhstan & Sri Lanka \\
\hline Burundi & Kenya & Sudan \\
\hline Cambodia & Korea, Dem. Rep. & Swaziland \\
\hline Cameroon & Kyrgyz Republic & Syrian Arab Republic \\
\hline Cape Verde & Laos & Tajikistan \\
\hline Central African Republic & Lebanon & Tanzania \\
\hline Chad & Lesotho & Thailand \\
\hline Chile & Liberia & Timor-Leste \\
\hline China & Lithuania & Togo \\
\hline Colombia & Macedonia & Tunisia \\
\hline Comoros & Madagascar & Turkey \\
\hline Congo, Dem. Rep. & Malawi & Turkmenistan \\
\hline Congo, Rep. & Mali & Uganda \\
\hline Costa Rica & Mauritania & Ukraine \\
\hline Cuba & Mauritius & Uruguay \\
\hline Côte d'Ivoire & Mexico & Uzbekistan \\
\hline Djibouti & Moldova & Venezuela \\
\hline Dominican Republic & Mongolia & Vietnam \\
\hline Ecuador & Morocco & Zambia \\
\hline Egypt, Arab Rep. & Mozambique & Zimbabwe \\
\hline El Salvador & Myanmar & \\
\hline Eritrea & Namibia & \\
\hline Ethiopia & Nepal & \\
\hline Fiji & Nicaragua & \\
\hline & & \\
\hline
\end{tabular}


Table A3: Electoral Competition, Democracy and Public Sector Corruption Effects on the Number of Greenfield Projects, Negative Binomial Regression Results, 1984-2012.

\begin{tabular}{|c|c|c|c|c|c|c|c|c|}
\hline & $(1)$ & (2) & (3) & (4) & $(5) \dagger$ & $(6) \ddagger$ & (7) & (8) \\
\hline & Elec. Theory & $\begin{array}{l}\text { Dem. } \\
\text { Theory }\end{array}$ & $\begin{array}{l}\text { Elec. } \\
\text { Theory }\end{array}$ & $\begin{array}{l}\text { Dem. } \\
\text { Theory }\end{array}$ & Elec. Full & Dem. Full & Elec. Full & Dem. Full \\
\hline \multirow[t]{2}{*}{ Public Sector Corruption } & $1.273^{* * *}$ & $1.038^{* * *}$ & 0.027 & -1.144 & $1.275^{* * *}$ & $0.982^{* * *}$ & -0.171 & $-1.522^{*}$ \\
\hline & $(0.452)$ & $(0.302)$ & $(0.744)$ & $(0.815)$ & $(0.453)$ & $(0.318)$ & $(0.780)$ & $(0.872)$ \\
\hline \multirow[t]{2}{*}{ Comp. Exec. Election $(=1)$} & $1.704^{* * *}$ & & $1.948^{* *}$ & & $1.568^{* * *}$ & & 1.107 & \\
\hline & $(0.333)$ & & $(0.967)$ & & $(0.334)$ & & $(0.983)$ & \\
\hline \multirow[t]{2}{*}{ CEE*Corruption } & $-1.168^{* *}$ & & $-2.373^{* * *}$ & & $-1.098^{* *}$ & & $-2.067^{* * *}$ & \\
\hline & $(0.472)$ & & $(0.687)$ & & $(0.469)$ & & $(0.673)$ & \\
\hline \multirow[t]{2}{*}{ Exec. Corr. Differential } & 0.108 & -0.387 & 3.404 & 3.071 & 0.047 & -0.158 & 3.844 & 3.680 \\
\hline & $(0.366)$ & $(0.372)$ & $(2.347)$ & $(2.424)$ & $(0.370)$ & $(0.374)$ & $(2.487)$ & $(2.572)$ \\
\hline \multirow[t]{2}{*}{ Democracy } & & $0.979^{* * *}$ & & 0.659 & & $0.968^{* * *}$ & & 0.260 \\
\hline & & $(0.206)$ & & $(0.657)$ & & $(0.216)$ & & $(0.604)$ \\
\hline \multirow[t]{2}{*}{ Democracy*Corruption } & & $-0.691^{* *}$ & & -0.665 & & $-0.923^{* * *}$ & & -0.472 \\
\hline & & $(0.296)$ & & $(0.459)$ & & $(0.307)$ & & $(0.434)$ \\
\hline \multirow[t]{2}{*}{ Avg. Agmts. Per Project } & & & & & $0.114^{* * *}$ & $0.109^{* * *}$ & $0.135^{* * *}$ & $0.132^{* * *}$ \\
\hline & & & & & $(0.006)$ & $(0.006)$ & $(0.009)$ & $(0.009)$ \\
\hline \multirow[t]{2}{*}{ Checks and Balances } & & & & & 0.031 & $0.066^{* * *}$ & $0.226^{* * *}$ & $0.197^{* * *}$ \\
\hline & & & & & $(0.022)$ & $(0.017)$ & $(0.062)$ & $(0.070)$ \\
\hline \multirow[t]{2}{*}{ Constant } & $-1.930^{* * *}$ & $-1.288^{* * *}$ & -0.477 & 0.537 & $-2.264^{* * *}$ & $-1.707^{* * *}$ & -0.821 & 0.019 \\
\hline & $(0.318)$ & $(0.206)$ & $(0.986)$ & $(0.704)$ & $(0.320)$ & $(0.222)$ & $(1.043)$ & $(0.853)$ \\
\hline Observations & 3088 & 3073 & 3212 & 3182 & 2989 & 2890 & 3125 & 3015 \\
\hline $\mathrm{BIC}$ & $4,932.042$ & $4,969.52$ & & & $4,507.19$ & 4.465 .174 & & \\
\hline Country Effects & Within & Within & Between & Between & Within & Within & Between & Between \\
\hline
\end{tabular}

Standard errors in parentheses. Significance: ${ }^{*} p<0.10,{ }^{* *} p<0.05,{ }^{* * *} p<0.01$. Between effects models report robust standard errors.

Preferred specifications for Figure $2(\dagger)$ and Figure $3(\dagger)$. 
Table A4: Electoral Competition, Democracy and Public Sector Corruption Effects on the Number of Greenfield Projects, Negative Binomial Regression Results, 1984-2012, Fixed Effect Models Only and No Interaction Terms.

\begin{tabular}{|c|c|c|c|c|c|c|c|c|}
\hline & $(1)$ & $(2)$ & $(3)$ & (4) & $(5)$ & $(6)$ & $(7)$ & (8) \\
\hline & $\begin{array}{l}\text { Elec. } \\
\text { Theory }\end{array}$ & Elec. Full & $\begin{array}{l}\text { Dem. } \\
\text { Theory }\end{array}$ & Dem. Full & $\begin{array}{c}\text { Elec. } \\
\text { Theory GF }\end{array}$ & $\begin{array}{l}\text { Elec. Full } \\
\text { GF }\end{array}$ & $\begin{array}{c}\text { Dem. } \\
\text { Theory GF }\end{array}$ & $\begin{array}{c}\text { Dem. Full } \\
\text { GF }\end{array}$ \\
\hline \multirow[t]{2}{*}{ Public Sector Corruption } & 0.328 & 0.300 & $0.702^{* * *}$ & $0.486^{* *}$ & 0.378 & 0.442 & $0.745^{* * *}$ & $0.573^{* *}$ \\
\hline & $(0.216)$ & $(0.224)$ & $(0.222)$ & $(0.230)$ & $(0.264)$ & $(0.274)$ & $(0.267)$ & $(0.278)$ \\
\hline \multirow[t]{2}{*}{ Democracy } & & & $0.523^{* * *}$ & $0.387^{* * *}$ & & & $0.528^{* * *}$ & $0.365^{* * *}$ \\
\hline & & & $(0.055)$ & $(0.060)$ & & & $(0.064)$ & $(0.070)$ \\
\hline \multirow[t]{2}{*}{ Comp. Exec. Election (=1) } & $0.932^{* * *}$ & $0.856^{* * *}$ & & & $0.934^{* * *}$ & $0.850^{* * *}$ & & \\
\hline & $(0.087)$ & $(0.100)$ & & & $(0.103)$ & $(0.118)$ & & \\
\hline \multirow[t]{2}{*}{ Exec. Corr. Differential } & -0.300 & -0.306 & $-0.592^{*}$ & -0.413 & 0.147 & 0.091 & -0.320 & -0.083 \\
\hline & $(0.315)$ & $(0.317)$ & $(0.320)$ & $(0.321)$ & $(0.366)$ & $(0.369)$ & $(0.368)$ & $(0.371)$ \\
\hline \multirow[t]{2}{*}{ Avg. Agmts. Per Project } & & $0.106^{* * *}$ & & $0.100^{* * *}$ & & $0.114^{* * *}$ & & $0.108^{* * *}$ \\
\hline & & $(0.005)$ & & $(0.005)$ & & $(0.006)$ & & $(0.006)$ \\
\hline \multirow[t]{2}{*}{ Checks and Balances } & & 0.025 & & $0.066^{* * *}$ & & 0.031 & & $0.068^{* * *}$ \\
\hline & & $(0.020)$ & & $(0.015)$ & & $(0.023)$ & & $(0.018)$ \\
\hline \multirow[t]{2}{*}{ Constant } & $-1.207^{* * *}$ & $-1.471^{* * *}$ & $-0.953^{* * *}$ & $-1.222^{* * *}$ & $-1.325^{* * *}$ & $-1.704^{* * *}$ & $-1.068^{* * *}$ & $-1.404^{* * *}$ \\
\hline & $(0.157)$ & $(0.165)$ & $(0.148)$ & $(0.158)$ & $(0.188)$ & $(0.198)$ & $(0.175)$ & $(0.188)$ \\
\hline Observations & 3204 & 3117 & 3166 & 2995 & 3088 & 2989 & 3073 & 2890 \\
\hline & & & & & & & & \\
\hline
\end{tabular}




\section{Appendix (Response Memorandum)}

We thank the referees and editor for their careful consideration of our manuscript and appreciate the helpful points to which we respond below. We were heartened to learn that R1 believed that we address an "interesting topic, such as whether corruption favors public-private initiative in the construction of public works". It was also reassuring to learn that R2 finds ours to be "a really interesting finding using novel data, and in an important administrative context". Responding to the comments in the referees' reports has strengthened our paper, and we detail those responses below, taking each report in turn. Comments from each report appear in italics and are followed by our responses.

\section{R1's Report}

I recommend the article by Giorgio Locatelli, Giacomo Mariani, Tristano Sainati and Marco Greco (2017): Corruption in public projects and megaprojects: There is an elephant in the room!, International Journal of Project Management, 35 (3), 252-268

We thank R1 for this helpful suggestion, which has informed the way in which we make our argument and our conclusions (see p. 20).

\section{R2's Report}

...the motivation, theory and discussion surrounding it are discursive and too long, as demonstrated by 6 1/2 pages of references (these could easily be two or three, for example by deleting the entire "grease vs. sand" discussion).

We appreciate the opportunity that $\mathrm{R} 2$ has given us to tighten our arguments and reduce some sections of the paper. We have cut the grease vs. sand discussion, and have also reduced the number of references in conjunction. See pp. 5-8.

... it seems like the authors could use a much simpler story. For example, (1): public-private partnerships are more likely when governments have an incentive to provide infrastructure services to citizens; those incentives rise with electoral pressures; (2) public-private partnerships are more likely when governments are corrupt, if one assumes that these partnerships are a particularly lowcost vehicle for rent-seeking; (3) Corrupt transactions are more risky and higher cost for the private sector in democracies than in non-democracies: in democracies, actors who are not party to corrupt transactions are more likely to have access to or control over the prosecutorial and fiduciary machinery of the state. Hence, because the costs of corrupt transactions are higher in democracies than non-democracies, private actors are more reluctant to engage in them. This offsets the rent-seeking incentives to do PPPs in corrupt democracies relative to corrupt nondemocracies. Points 1) and 2) are already made in the paper. Point 3) is all that is needed to justify the interaction term. I think this alternative framework is worthwhile just in terms of simplifying the storyline and applying Occam's Razor.

We thank R2 for this very helpful suggestion regarding the reworking of our theoretical section. R2 makes a valid point regarding the need to recognize more explicitly that bureaucratic corruption does not exist independently of the incentives of political actors and that it is contradictory to assume that competitive elections give politicians incentives to tamp down corrupt PPP transactions 
in corrupt democracies. We have rewritten the theoretical section at pp. 6-8 in accord with R2's suggestion. We believe that doing so has significantly strengthened our theory.

Regardless of the conceptual framework the authors eventually settle on, they should clarify whether the same predictions apply to all-public projects, and then explain why applying the same tests to a different dependent variable, public investment spending as a fraction of GDP, would not be appropriate (or, if appropriate, to present results using this dependent variable).

R2 rightly highlights that more time should be dedicated to whether our theoretical predictions apply to projects provided through full public management and we have addressed this at pp. 10-11. We also comment on why an alternative dependent variable such as public investment spending as a fraction of GDP would not be appropriate at p. 10.

Related to this, the authors should comment on why a "count" of projects, rather than either the absolute value of the projects or their value as a fraction of government spending, is a useful variable. What are the pros and cons? Are corruption and electoral regime likely to affect incentives to split a single infrastructure project into multiple projects, or to combine them?

We thank R2 for the opportunity to better clarify why we believe that the count of projects is the best measure for our model. We have commented upon this at greater length and have clarified the advantages and disadvantages of the measure at pp. 9-11.

It is important to say something about endogeneity. The issue is: what unobserved changes in a country can influence regime type, corruption and the turn towards public-private partnerships? For example, government fiscal conditions often affect whether they turn to privately-financed investment projects. Changes in those fiscal conditions might be related to changes in corruption and regime type that are used to identify the effects found in the regressions. The authors should at least present some intuition as to why unobserved changes in country conditions are unlikely to be driving both changes in the corruption/regime variables and in the number of infrastructure projects.

We agree that it is important to discuss this point and have included a section at pp. 18 that does so. We make three claims in that section First, bureaucratic corruption is notoriously persistent, meaning that it is unlikely to respond to broader changes or anything short of a direct, targeted campaign against corruption, and even such campaigns have been found to be ineffective (Meagher 2005, Svensson 2005, Persson et al. 2012). Second, while broader economic changes can influence electoral outcomes, it is unclear how they would influence bureaucratic corruption and we observe no such correlation. Bivariate within-country correlations between our corruption measure and the growth rate in GDP per capita and unemployment as a percentage of the labor force are not statistically significant. Moreover, the factors that determine whether or not elections are competitive (and whether this leads to politicians being more responsive to voters) have little scholarly consensus (cf. Ferejohn, 1977; Schantz, 1980; Grau, 1981; Patterson and Caldeia, 1983; Barrilleaux, 1986; Van Dunk and Weber, 1997; Abramowitz, Alexander and Gunning, 2006) and vary significantly from country to country (Gottlieb and Kosec, 2019). Third, although the private sector likely responds to economic improvement by seeking more involvement in infrastructure development, such changes are unlikely to have a strong effect on bureaucratic corruption and electoral competitiveness. The polyserial correlation between our dichotomous indicator of competitive elections and the continuous measures of growth rate of GDP per capita (0.066) and unemployment as a percentage of the labor force $(0.156)$ are low. And while good economic 
performance may increase the chance that an honest private partner seeks a project, we argue it is unlikely to disincentivize the partners-like those at the heart of our theory-who wish to selfenrich.

Finally, to be sure that peculiarities in the data are not driving the results, I would like to see the fixed effects specifications without the interaction term. The idea is to be sure that the estimated coefficients of corruption and elections remain reasonable (that is, don't switch signs or exhibit extraordinary changes in magnitudes).

We appreciate the opportunity to show these results and thank R2 for this helpful insight. We have included a table as part of the appendix (Table A4, p. 4) that shows the fixed effects specifications without the interaction term. As can be seen in the table, the corruption and elections (competitive elections and democracy-autocracy) coefficients remain consistent in terms of direction and do not exhibit extraordinary changes in magnitude.

\section{References}

Abramowitz, Alan I., Brad Alexander and Matthew Gunning. 2006. Incumbency, Redistricting, and the Decline of Competition in U.S. House Elections, The Journal of Politics, 68(1): 75-88.

Barrilleaux, Charles J. 1986. A dynamic model of partisan competition in the American states, American Journal of Political Science, 30(4): 822-840.

Ferejohn, John A. 1977. On the decline of competition in congressional elections, American Political Science Review, 71(1): 166-176.

Gottlieb, Jessica, and Katrina Kosec. 2019. The countervailing effects of competition on public goods provision: When bargaining inefficiencies lead to bad outcomes, American Political Science Review, 113(1): 88-107.

Grau, Craig H. 1981. Competition in state legislative primaries, Legislative Studies Quarterly, 6(1) 35-54.

Locatelli, Giorgio, Giacomo Mariani, Tristano Sainati, and Marco Greco. 2017. Corruption in public projects and megaprojects: There is an elephant in the room! International Journal of Project Management 35(3): 252-268.

Patterson, Samuel C., and Gregory A. Caldeira. 1983. The etiology of partisan competition, American Political Science Review, 78(3): 691-707.

Schantz, Harvey L. 1980. Contested and uncontested primaries for the US House, Legislative Studies Quarterly, 5(4): 545-562.

Van Dunk, Emily, and Ronald E. Weber. 1997. Constituency-level competition in the US states, 1968-1988: A pooled analysis, Legislative Studies Quarterly, 22(2): 141-159. 